\title{
PENGARUH MOTIVASI, KEMAMPUAN KERJA DAN FASILITAS KERJA TERHADAP KINERJA PEGAWAI DI KANTOR PELAYANAN PAJAK PRATAMA MEDAN PETISAH
}

\author{
Hery Irwansyah Sinaga \\ Universitas Islam Sumatera Utara \\ Hery.irwan@gmail.com
}

\begin{abstract}
The formulation of the problem in this research is how the influence of motivation on employees performance. How influence of work ability on employees performance. How influence of work facility on employees performance. How influence of motivation, work ability and work facility on employees performance. The purpose of this research is for know influence and analize of motivation on employees performance. For know influence and analize of work ability on employees performance. For know influence and analize work facility on employees performance. For know influence and analize motivation, work ability and work facility on employees performance. The sample in this research is 88 employees, with data analysis technique used is multiple linear regression analyze. The results of this research explain that motivation effect has a positive and significant on employee performance. Work ability effect has a positive and significant on employee performance. work facility effect has a positive and significant on employee performance. Motivation, work ability and work facility effect have a positive and significant on employee performance
\end{abstract}

Keywords :Motivation, Work Ability, Work Facility, Performance

\begin{abstract}
ABSTRAK : Rumusan masalah dalam penelitian ini adalah bagaimana pengaruh motivasi terhadap kinerja pegawai. Bagaimana pengaruh kemampuan kerja terhadap kinerja pegawai. Bagaimana pengaruh fasilitas kerja terhadap kinerja pegawai. Bagaimana pengaruh motivasi, kemampuan kerja dan fasilitas kerja terhadap kinerja pegawai. Tujuan penelitian ini adalah untuk mengetahui dan menganalisis pengaruh motivasi terhadap kinerja pegawai. Untuk mengetahui dan menganalisis pengaruh kemampuan kerja terhadap kinerja pegawai. Untuk mengetahui dan menganalisis pengaruh fasilitas kerja terhadap kinerja pegawai. Untuk mengetahui dan menganalisis pengaruh motivasi, kemampuan kerja dan fasilitas kerja terhadap kinerja pegawai. Sampel dalam penelitian ini berjumlah 88 orang pegawai. Teknik analisis data dalam penelitian ini menggunakan analisis deskriptif dan analisis regresi linier berganda. Hasil penelitian ini menjelaskan bahwa motivasi berpengaruh positif dan signifikan terhadap kinerja pegawai. Kemampuan kerja berpengaruh positif dan signifikan terhadap kinerja pegawai. Fasilitas kerja berpengaruh positif dan signifikan terhadap kinerja pegawai. Motivasi, kemampuan kerja dan fasilitas kerja berpengaruh positif dan signifikan terhadap kinerja pegawai
\end{abstract}

Kata Kunci : Motivasi, Kemampuan Kerja, Fasilitas Kerja, Kinerja Pegawai

\section{Pendahuluan}

Menurut pendapat Gibson at.al (2009:225) kinerja adalah sebagai bentuk seperangkat hasil yang diperoleh selama periode tertentu, tidak berhubungan dengan sifat, karakteristik pribadi, kompetensi. Jadi Gibson berpendapat diperlukan perbedaan yang jelas antara pengukuran pegawai dan pengukuran kinerja. Gibson at.al (2009:227) juga mengemukakan bahwa kinerja sebagai out come yang pertama behavior yaitu meliputi tentang kepuasan kerja, performance, absen, pergantian, kecelakaan, penyalahgunaan, kepedulian terhadap kesehatan, yang kedua kognitif dan yang ketiga psysiological.

Penelitian tentang kinerja telah banyak dilakukan oleh para peneliti sebelumnya. Berdasarkan penelusuran studi empiris dari Yeltsin Aprrioke Thomas (2010), faktor yang mempengaruhi kinerja adalah fasilitas kerja. Meskipun fasilitas kerja hanya sebagian kecil dari faktor- faktor yang mempengaruhi kinerja, 
namun keberadaannya tidak dapat diabaikan begitu saja. Sebab tanpa adanya fasilitas kerja, kegiatan organisasi tidak akan dapat terlaksana dengan baik sesuai dengan tujuan yang diharapkan. Fasilitas kerja sangat dibutuhkan dalam kegiatan organisasi secara formal yang pada umumnya berlangsung di suatu organisasi. Menurut Nitisemito (2009:88) mengemukakan bahwa fasilitas kerja merupakan kelengkapan kerja yang harus dimiliki oleh organisasi. Ruang kerja dan perlengkapan kantor yang baik sangat mendukung kenyamanan pegawai yang akan meningkatkan efisiensi dan efektifitasnya dalam bekerja. Fasilitas kerja Kantor Pelayanan Pajak Pratama Medan Petisah saat ini dapat dikategorikan masih kurang ptimal dalam mensuport kinerja pegawai, hal ini disebabkan terkadang masih adanya gangguan internet untuk pelayanan on line pada saat pelayanan ke wajib pajak.

Berdasarkan studi empiris dari Regina Aditya Reza (2010), faktor yang mempengaruhi kinerja adalah motivasi. Seorang yang memiliki motivasi yang rendah mereka cenderung untuk memperlihatkan upaya yang tidak maksimal dalam melaksanakan pekerjaannya, sehingga semakin tinggi motivasi yang dimiliki oleh individu sebagai pegawai maka dapat meningkatkan kinerja pegawai itu sendiri. Dengan demikian, setiap organisasi perlu mengetahui apa yang menjadi motivasi para pegawainya, sebab faktor tersebut dapat menjadi salah satu faktor yang menentukan tinggi atau rendahnya motivasi seorang pegawai dalam melaksanakan pekerjaan. Fenomena yang ditemukan pada pegawai Kantor Pelayanan Pajak Pratama Medan Petisah menunjukkan masih ada pegawai yang terlambat masuk kerja dan pulang sebelum jam kerja. Dari data rekapitusai absensi pengawai dapat dilihat bahwa rata-rata keterlambatan pegawai masuk kerja pada Tahun 2017 adalah $2.3 \%$ dan rata-rata pegawai yang pulang sebelum jam kerja adalah 2.2\%. Kondisi ini merefleksikan bahwa motivasi kerja pegawai Kantor Pelayanan Pajak Pratama Medan Petisah masih memerlukan perhatian.

Faktor berikutnya yang mempengaruhi kinerja pegawai Kantor Pelayanan Pajak Pratama Medan Petisah adalah kemampuan kerja. Studi empiris yang menunjukkan bahwa kemampuan kerja berpengaruh positif terhadap kinerja adalah penelitian dari Ageng Prawatya (2015). Handoko (2008:87), menyatakan kemampuan kerja adalah sejumlah kemampuan dasar yang dimliki oleh seseorang dan digunakan untuk memecahkan permasalahan baik yang dialami diri sendiri maupun di lingkungan. Sehingga dengan berfikir secara rasional ini seorang pegawai akan mampu untuk bertindak secara terarah dan menghadapi lingkungannya secara efektif. Kemampuan kerja seseorang menunjukkan tingkat kecerdasan. Sedangkan motivasi kerja merupakan kekuatan pendorong bagi seorang pegawai untuk melakukan sesuatu dalam mencapai tujuan. Semakin tinggi kemampuan kerja dan motivasi kerja seseorang maka semakin tinggi pula kinerjanya, begitu pula sebaliknya. Faktor-faktor yang mempengaruhi kemampuan kerja seorang pegawai antara lain pembawaan, kematangan, pembentukan, minat, kebebasan. Berkaitan dengan hal tersebut, kenyataan di lapangan terlihat bahwa kemampuan kerja yang dimiliki pegawai terlihat belum optimal, hal ini mungkin disebabkan karena kebebasan pegawai dalam berkreasi kurang diberi kesempatan, dan bidang tugas yang menjadi tanggung jawab pegawai ada yang kurang sesuai dengan latar belakang yang dimiliki oleh pegawai tersebut

Adapun tujuan penelitian ini adalah :

a. Untuk mengetahui dan menganalisis pengaruh motivasi terhadap kinerja pegawai di Kantor Pelayanan Pajak Pratama Medan Petisah.

b. Untuk mengetahui dan menganalisis pengaruh kemampuan kerja terhadap kinerja pegawai di Kantor Pelayanan Pajak Pratama Medan Petisah.

c. Untuk mengetahui dan menganalisis pengaruh fasilitas kerja terhadap kinerja pegawai di Kantor Pelayanan Pajak Pratama Medan Petisah

d. Untuk mengetahui dan menganalisis pengaruh motivasi, kemampuan kerja dan fasilitas kerja terhadap kinerja pegawai di Kantor Pelayanan Pajak Pratama Medan Petisah.

\section{Metode Penelitian \\ 2.1. Lokasi Penelitian}

Penelitian ini dilakukan di Kantor Pelayanan Pajak Pratama Medan Petisah. Jalan Asrama No. 7A Sikambing C II Medan

\subsection{Populasi}

Menurut Sugiyono (2004:90) populasi adalah wilayah generasi yang terdiri dari atas objek/subjek yang mempunyai kualitas 
karakteristik tertentu yang disajikan oleh peneliti untuk dipelajari dan kemudian ditarik kesimpulannya. Berdasarkan defenisi tersebut, maka populasi dalam penelitian ini adalah para pegawai Kantor Pelayanan Pajak Pratama Medan Petisah yang berjumlah 113 orang, dimana Kepala Kantor dan peneliti tidak dimasukkan sebagai populasi dengan rincian sebagai berikut :

\subsection{Sampel}

Untuk menentukan jumlah sampel, digunakan pendapat Slovin dalam Sekaran dan Bougie (2010:112) dengan menggunakan formula sebagai berikut :

Keterangan :

$$
n=\frac{N}{1+N \mathrm{e}^{2}}
$$

$\mathrm{n}$ : Jumlah Sampel

\subsection{Defenisi Operasional Variabel}

Tabel 1

Defenisi Operasional Variabel

\begin{tabular}{|c|c|c|c|c|}
\hline No & Defenisi & Variabel & $\begin{array}{c}\text { Indikator } \\
\text { Pengukuran }\end{array}$ & $\begin{array}{c}\text { Skala } \\
\text { Pengukuran }\end{array}$ \\
\hline 1. & $\begin{array}{l}\text { Kinerja adalah hasil kerja secara } \\
\text { kualitas dan kuantitas yang dicapai } \\
\text { oleh seorang pegawai dalam } \\
\text { melaksanakan tugasnya sesuai dengan } \\
\text { tanggung jawab yang diberikannya. } \\
\text { Siagian (2008:67). }\end{array}$ & $\begin{array}{l}\text { Variabel } \\
\text { terikat }\end{array}$ & $\begin{array}{l}\text { 1) Kualitas kerja } \\
\text { 2) Kuantitas kerja } \\
\text { 3) Kerjasama } \\
\text { 4) Out put kerja } \\
\text { 5) Waktu } \\
\text { Siagian (2008:78) }\end{array}$ & $\begin{array}{l}\text { Skala } \\
\text { Likert }\end{array}$ \\
\hline No & Defenisi & Variabel & $\begin{array}{c}\text { Indikator } \\
\text { Pengukuran }\end{array}$ & $\begin{array}{c}\text { Skala } \\
\text { Pengukuran }\end{array}$ \\
\hline 2. & $\begin{array}{l}\text { Kemampuan kerja adalah kemampuan } \\
\text { mental yang diperlukan untuk } \\
\text { menjalankan kegiatan mental. } \\
\text { Robbins }(2009: 46)\end{array}$ & $\begin{array}{c}\text { Variabel } \\
\text { bebas }\end{array}$ & $\begin{array}{l}\text { 1) Kemahiran } \\
\text { 2) Pemahaman } \\
\text { 3) Penalaran } \\
\text { 4) Visualisasi } \\
\text { 5) Ingatan } \\
\text { Robbins (2001:57) }\end{array}$ & $\begin{array}{l}\text { Skala } \\
\text { Ordinal }\end{array}$ \\
\hline 3. & $\begin{array}{l}\text { Fasilitas kerja merupakan } \\
\text { kelengkapan kerja yang harus dimiliki } \\
\text { oleh organisasi. } \\
\text { Sanusi (2005: 44) }\end{array}$ & $\begin{array}{c}\text { Variabel } \\
\text { bebas }\end{array}$ & $\begin{array}{l}\text { 1) Kendaraan dinas } \\
\text { 2) Rumah Dinas } \\
\text { 3) Meja, kursi kerja } \\
\text { 4) IT } \\
\text { 5) Penerangan } \\
\text { 6) Keasrian ruang } \\
\text { kerja } \\
\text { Sanusi (2005: 51) }\end{array}$ & $\begin{array}{l}\text { Skala } \\
\text { Ordinal }\end{array}$ \\
\hline 4 & $\begin{array}{l}\text { Motivasi kerja adalah daya dorong } \\
\text { bagi seseorang untuk memberikan } \\
\text { kontribusi yang sebesar-besarnya } \\
\text { demi keberhasilan organisasi } \\
\text { mencapai tujuannya. } \\
\text { Siagian (2008:87) }\end{array}$ & $\begin{array}{l}\text { Variabel } \\
\text { bebas }\end{array}$ & 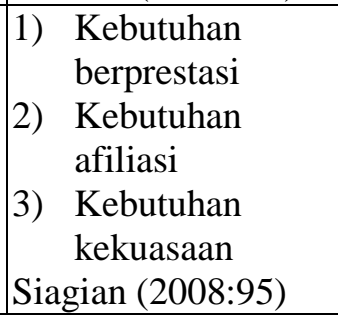 & $\begin{array}{l}\text { Skala } \\
\text { Ordinal }\end{array}$ \\
\hline
\end{tabular}

Sumber : Robbins (2009), Sanusi (2005), Siagian (2008)
N : Jumlah Populasi

$e$ : Kesalahan yang ditolerir dalam penarikan sampel yaitu 0,05 .

Berdasarkan formula diatas, selanjutnya dapat dihitung jumlah sampel dalam penelitian ini sebagai berikut :

$$
\begin{aligned}
& \mathrm{n}=\frac{113}{1+113(0,05)^{2}} \\
& \mathrm{n}=\frac{113}{1.28} \\
& \mathrm{n}=88.28=88 \text { orang }
\end{aligned}
$$

Setelah perhitungan di atas, penetapan jumlah sampel dalam penelitian ini menggunakan metode stratified random sampling yaitu penarikan sampel berdasarkan pada strata populasi pada setiap bagian, sehingga sampel dalam penelitian ini berjumlah 88 orang pegawai. 


\subsection{Pengujian Kualitas Data \\ 2.5.1. Uji Validitas}

Uji validitas digunakan untuk mengukur sah atau valid tidaknya suatu kuesioner. Suatu kuesioner dikatakan valid jika pertanyaan pada kuesioner mampu untuk mengungkapkan sesuatu yang akan diukur oleh kuesioner tersebut. Metode yang digunakan untuk menguji validitas adalah melakukan korelasi antar skor butir pertanyaan dengan total skor konstruk atau variabel. Pengujian validitas dilakukan dengan melakukan korelasi bilvariate antara masing-masing skor indikator dengan total skor konstruk. Hasil analisis korelasi bilvariate dengan melihat output Pearson Correlation, dengan ketentuan :

1) $r$ hitung $>r$ tabel, maka instrumen yang digunakan dinyatakan valid.

2) $r$ hitung $<r$ tabel, maka instrumen yang digunakan dinyatakan tidak valid.

\subsubsection{Uji Reliabilitas}

Uji reliabilitas sebenarnya adalah alat untuk mengukur suatu kuesioner yang merupakan indikator dari variabel atau konstruk. Suatu kuesioner dikatakan reliable atau handal jika jawaban seseorang terhadap pernyataan adalah konsisten atau stabil dari waktu ke waktu. Menurut Triton (2006:57) pengukuran reliabilitas dapat dilakukan dengan dua cara yaitu :

a. Repeated Measure arau pengukuran ulang

Disini seseorang akan disodori pertanyaan yang sama pada waktu yang berbeda, dan kemudian dilihat apakah ia tetap konsisten dengan jawabannya.

b. One Shot atau pengukuran sekali saja

Disini pengukurannya hanya sekali saja dan kemudian hasilnya dibandingkan dengan pertanyaan lain atau mengukur korelasi antar jawaban pertanyaan. Program SPSS yang memberikan fasilitas untuk mengukur reliabilitas dengan uji statistik Cronbach Alpha. Suatu konstruk atau variabel dikatakan reliabel jika memberikan nilai Cronbach Alpha > 0,60. Dalam penelitian ini menggunakan one shot supaya lebih efisien dalam waktu penyelesaian penelitian.

\subsection{Uji Asumsi Klasik}

\subsubsection{Uji Normalitas}

Uji normalitas bertujuan untuk menguji apakah dalam model regresi datanya terdistribusi normal atau tidak, model regresi yang baik jika distribusi datanya mengikuti distribusi normal atau mendekati normal, caranya adalah dengan melihat normal probability plot yang membandingkan distribusi kumulatif dari data sesungguhnya dengan distribusi kumulatif dari distribusi normal. Distribusi normal akan membentuk satu garis lurus diagonal, dan ploting data akan dibandingkan dengan garis diagonal. Jika distribusi data adalah normal, maka garis yang menggambarkan data sesungguhnya akan mengikuti garis diagonalnya atau dengan melihat kemencengan (skewness) dari grafik histogram.

\subsubsection{Uji Multikolinearitas}

Uji Multkolinearitas bertujuan untuk mengetahui ada tidaknya variabel independen yang memiliki kemiripan dengan variabel independen lainnya dalam suatu model regresi, atau untuk mengetahui ada tidaknya korelasi diantarasesama variabel independen. Uji Multikolinearitas dilakukan denganmembandingkan nilai toleransi (tolerance value) dan nilai Variance Inflation Factor (VIF) dengan nilai yang disyaratkan. Nilai yang disyaratkan bagi nilaitoleransi adalah lebih besar dari 0,01, dan untuk nilai VIF kurang dari 10.

\subsubsection{Uji Heteroskedastisitas}

Uji Heteroskedastisitas bertujuan menguji apakah dalam model regresi terjadi ketidaksamaan varian dari residual satu pengamatan ke pengamatan yang lain. Jika varian dari residual satu pengamatan ke pengamatan yang lain tetap, maka disebut Homoskedastisitas dan jika berbeda disebut Heteroskedastisitas. Selain diukur dengan grafik Scaterplot, heteroskedastisitas dapat diukur secara sistematis dengan uji Glejser. Jika variabel bebas signifikan secara statistik mempengaruhi variabel terikat, maka ada indikasi terjadi heteroskedastisitas. Jika probabilitas signifikansinya di atas 0,05 , maka dapat disimpulkan tidak terjadi heteroskedastisitas.Gejala heteroskedastisitas dalam penelitian ini dideteksi dengan menggunakan grafik scatterplot. Pendeteksian mengenai ada tidaknya heteroskedastisitas dapat dilakukan dengan melihat ada tidaknya pola tertentu pada grafik scatterplot antara SRESID dan ZPRED dimana sumbu $Y$ yang telah dipredkisi, dan sumbu $\mathrm{X}$ adalah residual yang telah di-studentized. Adapun dasar analisisnya sebagai berikut : 
a. Jika ada pola tertentu, seperti titik-titik yang ada membentuk pola tertentu yang teratur (bergelombang, melebar kemudian menyempit), maka mengindikasikan bahwa telah terjadi heteroskedastisitas.

b. Jika tidak ada pola yang jelas, serta titik-titik menyebar diatas dan dibawah anka nol pada sumbu $\mathrm{Y}$, maka tidak terjadi heteroskedastisitas.

\subsection{Pengujian Hipotesis}

Dalam penelitian ini untuk menguji hipotesis penelitian menggunakan analisis regresi linier berganda yaitu melihat pengaruh variabel independent (variabel bebas) terhadap variabel dependent (variabel terikat), dengan menggunakan persamaan matematis yaitu analisis regresi linier berganda dengan rumus :

Dimana :

$$
Y=a+b 1 X 1+b 2 X 2+b 3 X 3+e
$$

$$
\begin{array}{ll}
\mathrm{Y} & =\text { Kinerja Pegawai } \\
\mathrm{a} & =\text { Konstanta } \\
\mathrm{X} 1 & =\text { Motivasi } \\
\mathrm{X} 2 & =\text { Kemampuan kerja } \\
\mathrm{X} 3 & =\text { Fasilitas kerja } \\
\mathrm{b} 1, \mathrm{~b} 2, \mathrm{~b} 3 & =\text { Koefisien regresi } \\
\mathrm{e} & =\text { Standard error }
\end{array}
$$

Analisis regresi linier berganda meliputi uji Koefisien Determinasi $\left(\mathrm{R}^{2}\right)$ bertujuan untuk melihat sumbangan efektif variabel $\mathrm{X}_{1}, \mathrm{X}_{2}$, dan $\mathrm{X}_{3}$ dalam menjelaskan variabel $\mathrm{Y}$, uji $\mathrm{F}$ bertujuan melihat pengaruh secara simultan variabel $\mathrm{X}_{1}, \mathrm{X}_{2}$ dan $\mathrm{X}_{3}$ terhadap variabel $\mathrm{Y}$ dan uji $\mathrm{t}$ untuk melihat pengaruh secara parsial masing-masing variabel $X_{1}, X_{2}$ dan $X_{3}$ terhadap variabel $\mathrm{Y}$, dan lebih lengkapnya dapat dilihat penjelasan berikut ini :

\subsection{Uji F (Pengujian Simultan)}

Pengujian ini dilakukan untuk mengetahui apakah semua variabel independen secara bersama-sama (simultan) dapat berpengaruh terhadap variabel dependent. Cara yang digunakan adalah dengan membandingkan nilai $\mathrm{F}_{\text {hitung }}$ dengan $\mathrm{F}_{\text {tabel }}$ dengan ketentuan sebagai berikut :

H0 : $\beta=0$, berarti tidak ada pengaruh signifikan dari variabel independen terhadap variabel dependen secara simultan.

Ha : $\beta>0, \quad$ berarti ada pengaruh yang signifikan dari variabel independen terhadap variabel dependen secara simultan.
Tingkat kepercayaan yang digunakan adalah 95\% atau taraf signifikan 5\% $(\alpha=0,05)$ dengan kriteria sebagai berikut :

a. Jika $F_{\text {hitung }}>F_{\text {tabel }}$ dan probabilitas (nilai signifikan $)<$ tingkat signifikansi 5\% $(\alpha=$ $0,05)$ maka $\mathrm{Ha}$ diterima dan $\mathrm{H}_{0}$ ditolak berarti variabel independent secara bersamasama mempunyai pengaruh yang signifikan terhadap variabel dependent.

b. Jika $F_{\text {hitung }}<\mathrm{F}_{\text {tabel }}$ dan probabilitas (nilai signifikansi) $>$ tingkat signifikansi $5 \%(\alpha=$ $0,05)$ maka H0 diterima dan Ha ditolak berarti variabel independent secara bersamasama tidak mempunyai pengaruh yang signifikan terhadap variabel dependent.

Dimana nilai $\mathrm{F}_{\text {tabel }}$ ditentukan dengan mencari derajat bebasnya yaitu df $1=\mathrm{k}-1$ dan $\mathrm{df} 2=\mathrm{N}-\mathrm{k}$, dimana $\mathrm{N}=$ jumlah sampel dan $\mathrm{k}=$ jumlah variabel.

\subsection{Uji t (Pengujian Secara Parsial)}

Uji t dilakukan untuk mengetahui pengaruh masing-masing variabel independen secara parsial terhadap variabel dependen. Uji t dilakukan dengan membandingkan $t_{\text {hitung }}$ terhadap $\mathrm{t}_{\text {tabel }}$ dengan ketentuan sebagai berikut

$\mathrm{H} 0: \beta=0$, berarti tidak ada pengaruh signifikan dari masing-masing variabel independent terhadap variabel dependent.

$\mathrm{Ha}: \beta>0$, berarti ada pengaruh yang signifikan dari masing-masing variabel independent terhadap variabel dependent secara partial.

Tingkat kepercayaan yang digunakan adalah $95 \%$ atau taraf signifikan $5 \%(\alpha=0,05)$ dengan kriteria sebagai berikut :

1) Jika $t_{\text {hitung }}>t_{\text {tabel }}$ dan probabilitas (nilai signifikan $)<$ tingkat signifikansi $5 \%(\alpha=$ 0,05) maka $\mathrm{Ha}$ diterima dan $\mathrm{H}_{0}$ ditolak berarti ada pengaruh yang signifikan dari masing-masing variabel independent terhadap variabel dependent.

2) Jika $t_{\text {hitung }}<t_{\text {tabel }}$ dan probabilitas (nilai signifikansi) $>$ tingkat signifikansi $5 \%(\alpha=$ $0,05)$ maka H0 diterima dan $\mathrm{Ha}$ ditolak berarti tidak ada pengaruh yang signifikan dari masing-masing variabel independent terhadap variabel dependent.

Dimana nilai $t_{\text {tabel }}$ ditentukan dengan mencari derajat bebasnya yaitu $\mathrm{df}=\mathrm{N}-\mathrm{k}$.

\subsection{Koefisien Determinasi $\left(\mathbf{R}^{2}\right)$}

Koefisien determinasi $\left(\mathrm{R}^{2}\right)$ pada intinya mengukur seberapa besar kemampuan variabel independent yaitu $\mathrm{X}_{1}, \mathrm{X}_{2}$ dan $\mathrm{X}_{3}$ dalam 
menerangkan variasi variabel dependent (Y). Nilai koefisien determinasi adalah antara nol (0) sampai dengan satu (1). Nilai $\mathrm{R}^{2}$ yang kecil berarti kemampuan variabel-variabel independent dalam menjelaskan variasi variabel dependent amat terbatas. Nilai yang mendekati satu berarti variabel-variabel independent memberikan hampir semua informasi yang dibutuhkan untuk memprediksi variasi dependent. Secara umum koefisien determinasi untuk data silang (crosssection) relatif rendah karena adanya variasi yang besar antara masing-masing pengamatan, sedangkan untuk data runtun waktu (time series) biasanya mempunyai nilai koefisien determinasi yang tinggi.

\section{Hasil dan Pembahasan \\ 3.1. Uji Validitas}

Uji validitas adalah uji statistik yang digunakan untuk menentukan seberapa valid suatu item pernyataan dalam mengukur variabel yang diteliti. Berikut ini hasil uji validitas dari keempat variabel yang diteliti.

Tabel 2

Out put uji vaiditas variabel motivasi

\begin{tabular}{|c|c|c|c|c|}
\hline Variabel & Angket & $\mathrm{r}>0.3$ & Sig $<0.05$ & Keterangan \\
\hline $\begin{array}{c}\text { Motivasi kerja } \\
\left(\mathrm{X}_{1}\right)\end{array}$ & $\mathrm{X}_{1.1}$ & 0.456 & 0.000 & Valid \\
\cline { 2 - 5 } & $\mathrm{X}_{1.2}$ & 0.500 & 0.000 & Valid \\
\cline { 2 - 5 } & $\mathrm{X}_{1.3}$ & 0.560 & 0.000 & Valid \\
\cline { 2 - 5 } & $\mathrm{X}_{1.4}$ & 0.624 & 0.000 & Valid \\
\cline { 2 - 5 } & $\mathrm{X}_{1.5}$ & 0.587 & 0.000 & Valid \\
\cline { 2 - 5 } & $\mathrm{X}_{1.6}$ & 0.643 & 0.000 & Valid \\
\cline { 2 - 5 } & $\mathrm{X}_{1.7}$ & 0.629 & 0.000 & Valid \\
\cline { 2 - 5 } & $\mathrm{X}_{1.8}$ & 0.775 & 0.000 & Valid \\
\cline { 2 - 5 } & $\mathrm{X}_{1.9}$ & 0.621 & 0.000 & Valid \\
\cline { 2 - 5 } & $\mathrm{X}_{1.10}$ & 0.652 & 0.000 & Valid \\
\hline
\end{tabular}

Sumber : Hasil Pengolahan Data, 2019

Dari Tabel 2, di atas dapat dijelaskan keseluruhannya dinyatakan valid, karena bahwa nilai signifikansi butir-butir nilai korelasinya lebih besar dari 0.3 dan pernyataan untuk variabel motivasi nilai signifikansinya di bawah 0.05 .

\section{Tabel 3}

Out put uji vaiditas variabel kemampuan kerja

\begin{tabular}{|c|c|c|c|c|}
\hline Variabel & Angket & $\mathrm{r}>0.3$ & Sig $<0.05$ & Keterangan \\
\hline Kemampuan kerja & $\mathrm{X}_{2.1}$ & 0.763 & 0.000 & Valid \\
\cline { 2 - 5 }$\left(\mathrm{X}_{2}\right)$ & $\mathrm{X}_{2.2}$ & 0.866 & 0.000 & Valid \\
\cline { 2 - 5 } & $\mathrm{X}_{2.3}$ & 0.549 & 0.000 & Valid \\
\cline { 2 - 5 } & $\mathrm{X}_{2.4}$ & 0.611 & 0.000 & Valid \\
\cline { 2 - 5 } & $\mathrm{X}_{2.5}$ & 0.768 & 0.000 & Valid \\
\cline { 2 - 5 } & $\mathrm{X}_{2.6}$ & 0.329 & 0.002 & Valid \\
\cline { 2 - 5 } & $\mathrm{X}_{2.7}$ & 0.782 & 0.000 & Valid \\
\cline { 2 - 5 } & $\mathrm{X}_{2.8}$ & 0.688 & 0.000 & Valid \\
\cline { 2 - 5 } & $\mathrm{X}_{2.9}$ & 0.657 & 0.000 & Valid \\
\cline { 2 - 5 } & $\mathrm{X}_{2.10}$ & 0.758 & 0.000 & Valid \\
\hline
\end{tabular}

Sumber : Hasil Pengolahan Data, 2019

Dari Tabel 3, di atas dapat dijelaskan kerja keseluruhannya dinyatakan valid, bahwa nilai signifikansi butir-butir karena nilai korelasinya lebih besar dari 0.3 pernyataan untuk variabel kemampuan dan nilai signifikansinya di bawah 0.05 . Tabel 4

Out put uji vaiditas variabel fasilitas kerja

\begin{tabular}{|c|c|c|c|c|}
\hline Variabel & Angket & $\mathrm{r}>0.3$ & Sig $<0.05$ & Keterangan \\
\hline Fasilitas kerja & $\mathrm{X}_{3.1}$ & 0.767 & 0.000 & Valid \\
\cline { 2 - 5 }$\left(\mathrm{X}_{3}\right)$ & $\mathrm{X}_{3.2}$ & 0.679 & 0.000 & Valid \\
\cline { 2 - 5 } & $\mathrm{X}_{3.3}$ & 0.607 & 0.000 & Valid \\
\hline
\end{tabular}




\begin{tabular}{|c|c|c|c|c|}
\hline Variabel & Angket & $\mathrm{r}>0.3$ & Sig $<0.05$ & Keterangan \\
\hline & $\mathrm{X}_{3.4}$ & 0.371 & 0.000 & Valid \\
\cline { 2 - 5 } & $\mathrm{X}_{3.5}$ & 0.410 & 0.000 & Valid \\
\cline { 2 - 5 } & $\mathrm{X}_{3.6}$ & 0.643 & 0.000 & Valid \\
\cline { 2 - 5 } & $\mathrm{X}_{3.7}$ & 0.394 & 0.000 & Valid \\
\cline { 2 - 5 } & $\mathrm{X}_{3.8}$ & 0.828 & 0.000 & Valid \\
\cline { 2 - 5 } & $\mathrm{X}_{3.9}$ & 0.878 & 0.000 & Valid \\
\cline { 2 - 5 } & $\mathrm{X}_{3.10}$ & 0.335 & 0.027 & Valid \\
\hline
\end{tabular}

Sumber : Hasil Pengolahan Data, 2019

Dari Tabel 4, di atas dapat dijelaskan keseluruhannya dinyatakan valid, karena bahwa nilai signifikansi butir-butir nilai korelasinya lebih besar dari 0.3 dan pernyataan untuk variabel fasilitas kerja nilai signifikansinya di bawah 0.05 .

Tabel 5

Out put uji vaiditas variabel kinerja

\begin{tabular}{|c|c|c|c|c|}
\hline Variabel & Angket & $\mathrm{r}>0.3$ & Sig $<0.05$ & Keterangan \\
\hline Kinerja & $\mathrm{Y}_{1}$ & 0.767 & 0.000 & Valid \\
\cline { 2 - 5 } & $\mathrm{Y}_{2}$ & 0.705 & 0.000 & Valid \\
\cline { 2 - 5 } & $\mathrm{Y}_{3}$ & 0.657 & 0.000 & Valid \\
\cline { 2 - 5 } & $\mathrm{Y}_{4}$ & 0.427 & 0.000 & Valid \\
\cline { 2 - 5 } & $\mathrm{Y}_{5}$ & 0.445 & 0.000 & Valid \\
\cline { 2 - 5 } & $\mathrm{Y}_{6}$ & 0.645 & 0.000 & Valid \\
\cline { 2 - 5 } & $\mathrm{Y}_{7}$ & 0.440 & 0.000 & Valid \\
\cline { 2 - 5 } & $\mathrm{Y}_{8}$ & 0.786 & 0.000 & Valid \\
\cline { 2 - 5 } & $\mathrm{Y}_{9}$ & 0.857 & 0.000 & Valid \\
\cline { 2 - 5 } & $\mathrm{Y}_{10}$ & 0.306 & 0.004 & Valid \\
\hline
\end{tabular}

Sumber : Hasil Pengolahan Data, 2019

Dari Tabel 5, di atas dapat dijelaskan keseluruhannya dinyatakan valid, karena bahwa nilai signifikansi butir-butir nilai korelasinya lebih besar dari 0.3 dan pernyataan untuk variabel kinerja nilai signifikansinya di bawah 0.05 .

\subsection{Uji Reliabilitas}

Uji reliabilitas adalah uji statistik yang digunakan untuk menentukan reliabilitas kehandalannya mengukur suatu variabel. Berikut ini hasil uji reliabilitas dari keempat serangkaian item pernyataan dalam

variabel yang diteliti.

Tabel 6

Uji Reliabilitas

\begin{tabular}{|l|c|c|c|}
\hline \multicolumn{1}{|c|}{ Variabel } & $\begin{array}{c}\text { Nilai Alpha } \\
\text { Cronbach's }\end{array}$ & Reliabel/Tidak Reliabel & Keterangan \\
\hline Motivasi $\left(\mathrm{X}_{1}\right)$ & 0.792 & Reliabel (Tinggi) & Dipakai \\
\hline Kemampuan Kerja $\left(\mathrm{X}_{2}\right)$ & 0.872 & Reliabel (Cukup) & Dipakai \\
\hline Fasilitas Kerja $\left(\mathrm{X}_{3}\right)$ & 0.762 & Reliabel (Tinggi) & Dipakai \\
\hline Kinerja (Y) & 0.794 & Reliabel (Cukup) & Dipakai \\
\hline
\end{tabular}

Sumber : Hasil Pengolahan Data, 2019

Dari Tabel 6, diatas, diketahui nilai $\mathrm{r}_{\text {tabel }}$ untuk uji dua sisi pada tingkat signifikan 5\% $(\alpha=$ 0,05 ), dengan jumlah sampel $\mathrm{N}=88$, maka derajat bebasnya adalah $\mathrm{N}-2=88-2=86$, dan diketahui nilai $\mathrm{r}_{\text {tabel }}=0.210$. Dari hasil pengolahan data penelitian diperoleh nilai $r_{\text {hitung }}$ pada kolom cronbach's alpha if item deleted semua lebih besar dari nilai $r_{\text {tabel}}$, maka seluruh butir pernyataan untuk variabel motivasi dinyatakan reliable.

\subsection{Uji Asumsi Klasik \\ 3.3.1. Uji Normalitas}

Uji normalitas adalah untuk melihat apakah nilai residual terdistribusi normal atau tidak. Model regresi yang baik adalah memiliki nilai residual yang terdistribusi 
normal. Jadi uji normalitas bukan dilakukan pada masing-masing variabel tetapi pada nilai residualnya. Sering terjadi kesalahan yang jamak yaitu bahwa uji normalitas dilakukan pada masing-masing variabel. Hal ini tidak dilarang tetapi model regresi memerlukan normalitas pada nilai residualnya bukan pada masing-masing variabel penelitian.

Pengujian normalitas data penelitian adalah untuk menguji apakah dalam model statistik variabel-variabel penelitian berdistribusi normal atau tidak normal. Model regresi yang tinggi adalah memiliki distribusi normal atau mendekati normal. Untuk menguji apakah distribusi data normal atau tidak, salah satunya dengan menggunakan metode gambar normal Probabilitas Plots digunakan untuk menyimpulkan apakah model analisis memenuhi asumsi normal, dengan penyebaran data di sekitar garis diagonal dan mengikuti arah garis diagonal maka data tersebut mememenuhi asumsi normal

Tabel 7

One-Sampel Kolmogorov-Smirnov Test

\begin{tabular}{|l|l|r|}
\hline \multicolumn{2}{|l|}{} & Unstandardized Residual \\
\hline $\mathrm{N}$ & Mean & 88 \\
\cline { 2 - 3 } Normal Parameters & Std. Deviation & $0 \mathrm{E}-7$ \\
\hline \multirow{3}{*}{ Most Extreme Differences } & Absolute & .166 \\
\cline { 2 - 3 } & Positive & .093 \\
\cline { 2 - 3 } & Negative & -.166 \\
\hline Kolmogorov-Smirnov Z & 1.555 \\
\hline Asymp. Sig. (2-tailed) & .116 \\
\hline Sumber: Hasil pengolahan data, 2019 &
\end{tabular}

Berdasarkan Tabel 5.16, diatas diketahui signifikansi sebesar 0.116. Nilai signifikansi ini lebih besar dari 0.05, sehingga dapat disimpulkan bahwa data yang diuji berdistribusi normal.

\subsubsection{Uji Multikolinieritas}

Multikolinieritas berarti adanya hubungan yang kuat diantara beberapa atau semua variabel bebas pada model regresi. Jika terdapat multikolinieritas maka koefisien regresi menjadi tidak tentu, tingkat kesalahannya menjadi sangat besar dan biasanya ditandai dengan koefisien determinasi yang sangat besar tetapi pada pengujian parsial koefisien regresi, tidak ada atau pun kalau ada sangat sedikit dalam model analisis, yang dapat dilihat pada gambar dibawah ini :

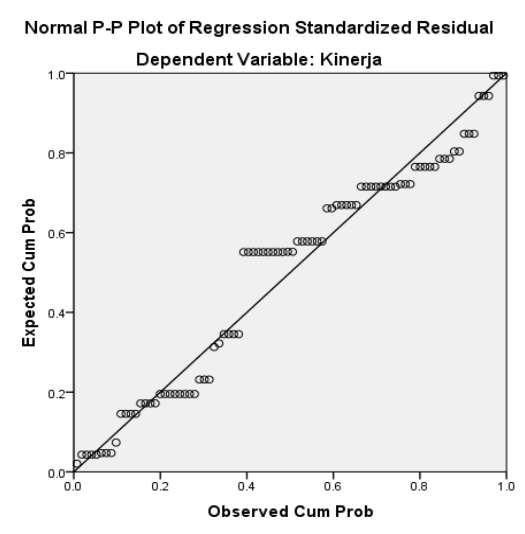

Gambar 1. Uji asumsi normalitas

Dari Gambar 1, diatas dapat dijelaskan bahwa penyebaran data berada di sekitar garis diagonal dan mengikuti arah garis diagonal, maka dapat ditarik kesimpulan data tersebut mememenuhi asumsi normal atau berdistribusi normal. Selanjutnya uji normalitas data juga dapat menggunakan uji Kolmogorov-Smirnov Test, dengan hasil sebagai berikut.

sekali koefisien regresi yang signifikan. Pada penelitian ini digunakan nilai Variance Inflantion Factorrs (VIF) sebagai indikator ada tidaknya multikolinearitas di antara variabel bebas.

Tabel 8

Uji asumsi multikolinieritas

\begin{tabular}{|l|c|c|}
\hline \multirow{2}{*}{ Variabel } & \multicolumn{2}{|c|}{ Collinearity Statistics } \\
\cline { 2 - 3 } & Tolerance & VIF \\
\hline Motivasi & 0.851 & 1.176 \\
\hline $\begin{array}{l}\text { Kemampuan } \\
\text { kerja }\end{array}$ & 0.679 & 1.474 \\
\hline Fasilitas kerja & 0.721 & 1.387 \\
\hline
\end{tabular}

a Dependent Variable : Kinerja 
Dari Tabel 8, dapat dijelaskan bahwa nilai Collinearity Statistics untuk nilai Variance Inflantion Factorrs (VIF) yang diperoleh dalam penelitian ini sebesar 1.176; 1.474; 1.387, dan nilai tolerance sebesar 0.851; 0.679; 0.721; dimana nilai Variance Inflantion Factorrs (VIF) dari ketiga varibel bebas dalam penelitian ini lebih kecil dari 10 dan dapat disimpulkan tidak terjadi multikolinieritas diantara ketiga variabel bebas dalam penelitian ini.

\subsubsection{Uji Autokorelasi}

Autokorelasi sebagai suatu korelasi antara nilai variabel dengan nilai variabel yang sama satu atau lebih. Menurut Cornelius (2005:212), kisaran nilai uji autokorelasi yang dilakukan dalam pengujian Durbin Watson (DW) sebagai berikut :

$1.65<\mathrm{DW}<2.35$ tidak terjadi autokorelasi

1.21. $<\mathrm{DW}<1.65$ atau $2.35<\mathrm{DW}<2.79$ tidak dapat disimpulkan.

$\mathrm{DW}<1.21$ atau $\mathrm{DW}>2.79$ terjadi autokorelasi.

Tabel 9

Model summary

\begin{tabular}{|l|r|r|r|r|r|c|}
\hline \multirow{4}{*}{ Model } & \multicolumn{5}{|c|}{ Change Statistics } & \multirow{2}{*}{$\begin{array}{c}\text { Durbin- } \\
\text { Watson }\end{array}$} \\
\cline { 2 - 7 } & $\begin{array}{c}\text { R Square } \\
\text { Change }\end{array}$ & F Change & df1 & df2 & $\begin{array}{c}\text { Sig. F } \\
\text { Change }\end{array}$ & \\
\hline 1 & .718 & 71.159 & 3 & 84 & .000 & 1.967 \\
\hline
\end{tabular}

a Predictors: (Constant), Motivasi, Kemampuan, Fasilitas

Dependent Variable : Kinerja

Berdasarkan Tabel 9, di atas diperoleh nilai statistik Durbin-Watson (DW) sebesar 1.967, nilai tersebut berada pada kisaran $1.65<\mathrm{DW}<$ 2.35 maka dapat disimpulkan tidak terdapat autokorelasi pada model regresi dalam penelitian ini.

\subsection{Analisis Regresi Linier Berganda}

Tabel 10

Coefficients $^{\mathrm{a}}$

\begin{tabular}{|c|c|c|c|c|c|c|}
\hline \multirow{2}{*}{\multicolumn{2}{|c|}{ Model }} & \multicolumn{2}{|c|}{$\begin{array}{l}\text { Unstandardized } \\
\text { Coefficients }\end{array}$} & \multirow{3}{*}{$\begin{array}{c}\text { Standardized } \\
\text { Coefficients } \\
\text { Beta } \\
\end{array}$} & \multirow{2}{*}{$\mathrm{t}$} & \multirow{2}{*}{ Sig. } \\
\hline & & \multirow{2}{*}{$\begin{array}{c}\mathrm{B} \\
3.253\end{array}$} & \multirow{2}{*}{$\begin{array}{r}\text { Std. Error } \\
2.874\end{array}$} & & & \\
\hline 1 & (Constant) & & & & 1.132 & .261 \\
\hline & Motivasi & .186 & .045 & .258 & 4.107 & .000 \\
\hline & Kemampuan kerja & .447 & .061 & .519 & 7.378 & .000 \\
\hline & Fasilitas kerja & .293 & .069 & .289 & 4.236 & .000 \\
\hline
\end{tabular}

a Dependent Variable : Kinerja

Berdasarkan Tabel 5.19, out put SPSS "Coefficients" diatas, persamaan regresi linier berganda adalah sebagai berikut :

$\mathrm{Y}=3.253+0.186 \mathrm{X} 1+0.447 \mathrm{X} 2+0.293 \mathrm{X} 3$

Berdasarkan persamaan regresi linier berganda ini, maka dapat dijelaskan maksud dari persamaan di atas :

1) Nilai konstanta dari persamaan regresi dari penelitian ini sebesar 3.253, hal ini menyatakan bahwa nilai variabel kinerja pegawai di Kantor Pelayanan Pajak Pratama Medan Petisah sebesar 3.253.
Analisis regresi linier berganda ini digunakan untuk mengestimasi pengaruh motivasi, kemampuan kerja dan fasilitas kerja terhadap kinerja pegawai di Kantor Pelayanan Pajak Pratama Medan Petisah. Berdasarkan hasil pengolahan data diperoleh hasil sebagai berikut : 
4) Koefisien regresi untuk variabel fasilitas kerja sebesar 0.293, hal ini menjelaskan bahwa variabel fasilitas kerja berpengaruh positif terhadap kinerja pegawai Kantor Pelayanan Pajak Pratama Medan Petisah.

Dari persamaan di atas dapat ditarik kesimpulan bahwa model regresi ini sudah layak dan benar, dan dapat dijelaskan bahwa variabel motivasi, kemampuan kerja dan fasilitas kerja berpengaruh positif terhadap kinerja pegawai di Kantor Pelayanan Pajak Pratama Medan Petisah.

\subsection{Uji Hipotesis}

3.5.1. Pengaruh Motivasi Terhadap Kinerja Pegawai di Kantor Pelayanan Pajak Pratama Medan Petisah.

Untuk mengetahui pengaruh motivasi terhadap kinerja pegawai di Kantor

Tabel. 11

Coeficients ${ }^{\mathrm{a}}$ pengaruh motivasi terhadap kinerja

\begin{tabular}{|c|c|c|c|c|c|c|}
\hline \multirow{2}{*}{\multicolumn{2}{|c|}{ Model }} & \multicolumn{2}{|c|}{$\begin{array}{l}\text { Unstandardized } \\
\text { Coefficients }\end{array}$} & \multirow{3}{*}{$\begin{array}{c}\text { Standardized } \\
\text { Coefficients } \\
\text { Beta }\end{array}$} & \multirow{2}{*}{$\mathrm{t}$} & \multirow{2}{*}{ Sig. } \\
\hline & & B & Std. Error & & & \\
\hline 1 & (Constant) & 3.253 & 2.874 & & 1.132 & .261 \\
\hline & Motivasi & .186 & .045 & .258 & 4.107 & .000 \\
\hline
\end{tabular}

Berdasarkan Tabel 11, out put SPSS "Coeficients" diatas diketahui nilai $t_{\text {hitung }}$ variabel motivasi sebesar 4.107. Karena nilai $t_{\text {hitung }}>t_{\text {tabel }}(4.107>1.988)$ dan nilai signifikasi $0.000<0.05$, sehingga $\mathrm{H}_{0}$ ditolak dan $\mathrm{H}_{1}$ diterima. Artinya hipotesis yang diajukan dalam penelitian ini diterima yaitu variabel motivasi secara partial berpengaruh positif dan signifikan terhadap kinerja pegawai di Kantor Pelayanan Pajak Pratama Medan Petisah. Hasil penelitian ini menjelaskan bahwa semakin baik motivasi maka semakin tinggi kinerja pegawai di Kantor Pelayanan Pajak Pratama Medan Petisah.

\subsubsection{Pengaruh Kemampuan Kerja Terhadap Kinerja Pegawai di Kantor Pelayanan Pajak Pratama Medan Petisah.}

Untuk mengetahui pengaruh kemampuan kerja terhadap kinerja pegawai di Kantor
Pelayanan Pajak Pratama Medan Petisah digunakan uji-t, dengan ketentuan sebagai berkut :

1) Jika nilai $t_{\text {hitung }}>t_{\text {tabel }}$ dan nilai probabilitas (p) $<$ tingkat signifikansi 5\% $(\alpha=0,05)$ maka hipotesis penelitian $\left(\mathrm{H}_{1}\right)$ diterima dan $\mathrm{H}_{0}$ ditolak, berarti ada pengaruh signifikan antara motivasi terhadap kinerja.

2) Jika nilai $t_{\text {hitung }}<t_{\text {tabel }}$ dan nilai probabilitas (p) > tingkat signifikansi 5\% $(\alpha=0,05)$ maka hipotesis penelitian $\left(\mathrm{H}_{1}\right)$ ditolak dan $\mathrm{H}_{0}$ diterima, berarti tidak ada pengaruh signifikan antara motivasi terhadap kinerja.

Penelitian ini menggunakan taraf signifikansi $(\alpha \quad 0,05)$ dan Derajat Kebebasan (DK) dengan ketentuan DK $=\mathrm{n}-2$, atau $88-2$ $=86$. Dengan ketentuan tersebut, diperoleh nilai $\mathrm{t}_{\text {tabel }}$ sebesar 1.988 .
Pelayanan Pajak Pratama Medan Petisah digunakan uji-t, dengan ketentuan sebagai berkut:

1) Jika nilai $t_{\text {hitung }}>t_{\text {tabel }}$ dan nilai probabilitas (p) $<$ tingkat signifikansi 5\% $(\alpha=0,05)$ maka hipotesis penelitian $\left(\mathrm{H}_{1}\right)$ diterima dan $\mathrm{H}_{0}$ ditolak, berarti ada pengaruh signifikan antara kemampuan kerja terhadap kinerja.

2) Jika nilai $t_{\text {hitung }}<t_{\text {tabel }}$ dan nilai probabilitas (p) > tingkat signifikansi 5\% $(\alpha=0,05)$ maka hipotesis penelitian $\left(\mathrm{H}_{1}\right)$ ditolak dan $\mathrm{H}_{0}$ diterima, berarti tidak ada pengaruh signifikan antara kemampuan kerja terhadap kinerja.

Penelitian ini menggunakan taraf signifikansi $(\alpha \quad 0,05)$ dan Derajat Kebebasan (DK) dengan ketentuan DK $=\mathrm{n}-2$, atau $88-2$ $=86$. Dengan ketentuan tersebut, diperoleh nilai $\mathrm{t}_{\text {tabel }}$ sebesar 1.988 . 
Tabel. 12

Coeficients $^{\mathrm{a}}$

\begin{tabular}{|c|c|c|c|c|c|c|}
\hline \multirow{2}{*}{\multicolumn{2}{|c|}{ Model }} & \multicolumn{2}{|c|}{$\begin{array}{l}\text { Unstandardized } \\
\text { Coefficients }\end{array}$} & \multirow{3}{*}{$\begin{array}{c}\text { Standardized } \\
\text { Coefficients } \\
\text { Beta }\end{array}$} & \multirow{2}{*}{$\mathrm{t}$} & \multirow{2}{*}{ Sig. } \\
\hline & & B & Std. Error & & & \\
\hline 1 & (Constant) & 3.253 & 2.874 & & 1.132 & 261 \\
\hline & Kemampuan kerja & .447 & .061 & .519 & 7.378 & .000 \\
\hline
\end{tabular}

Berdasarkan Tabel 12, out put SPSS "Coeficients" diatas diketahui nilai $t_{\text {hitung }}$ variabel efikasi diri sebesar 7.378. Karena nilai $t_{\text {hitung }}>t_{\text {tabel }}(7.378>1.988)$ dan nilai signifikasi $0.000<0.05$, sehingga $\mathrm{H}_{0}$ ditolak dan $\mathrm{H}_{1}$ diterima. Artinya hipotesis yang diajukan dalam penelitian ini diterima yaitu variabel kemampuan kerja secara partial berpengaruh positif dan signifikan terhadap kinerja pegawai di Kantor Pelayanan Pajak Pratama Medan Petisah. Hasil penelitian ini menjelaskan bahwa semakin baik kemampuan kerja maka semakin tinggi kinerja pegawai di Kantor Pelayanan Pajak Pratama Medan Petisah.

\subsubsection{Pengaruh Fasilitas Kerja Terhadap Kinerja Pegawai di Kantor Pelayanan Pajak Pratama Medan Petisah.}

Untuk mengetahui pengaruh fasilitas kerja terhadap kinerja pegawai di Kantor
Pelayanan Pajak Pratama Medan Petisah digunakan uji-t, dengan ketentuan sebagai berkut:

1) Jika nilai $t_{\text {hitung }}>t_{\text {tabel }}$ dan nilai probabilitas $(p)<$ tingkat signifikansi 5\% $(\alpha=0,05)$ maka hipotesis penelitian $\left(\mathrm{H}_{1}\right)$ diterima dan $\mathrm{H}_{0}$ ditolak, berarti ada pengaruh signifikan antara fasilitas kerja terhadap kinerja.

2) Jika nilai $t_{\text {hitung }}<t_{\text {tabel }}$ dan nilai probabilitas (p) > tingkat signifikansi 5\% $(\alpha=0,05)$ maka hipotesis penelitian $\left(\mathrm{H}_{1}\right)$ ditolak dan $\mathrm{H}_{0}$ diterima, berarti tidak ada pengaruh signifikan antara fasilitas kerja terhadap kinerja.

Penelitian ini menggunakan taraf signifikansi $\left(\begin{array}{ll}\alpha & 0,05\end{array}\right)$ dan Derajat Kebebasan (DK) dengan ketentuan DK $=\mathrm{n}-2$, atau $88-2$ $=86$. Dengan ketentuan tersebut, diperoleh nilai $\mathrm{t}_{\text {tabel }}$ sebesar 1.988 .

Tabel. 13

Coeficients ${ }^{\mathrm{a}}$ pengaruh fasilitas kerja terhadap kinerja

\begin{tabular}{|l|l|r|r|r|r|r|}
\hline \multirow{2}{*}{ Model } & \multicolumn{2}{|c|}{$\begin{array}{c}\text { Unstandardized } \\
\text { Coefficients }\end{array}$} & $\begin{array}{c}\text { Standardized } \\
\text { Coefficients } \\
\text { Beta }\end{array}$ & t & \multirow{2}{*}{ Sig. } \\
\cline { 3 - 6 } \multicolumn{2}{|c|}{} & B & Std. Error & & \\
\hline 1 & (Constant) & 3.253 & 2.874 & & 1.132 & .261 \\
\hline & Fasilitas kerja & .293 & .069 & .289 & 4.236 & .000 \\
\hline
\end{tabular}

a Dependent Variable : Kinerja

Berdasarkan Tabel 13, out put SPSS "Coeficients" diatas diketahui nilai $t_{\text {hitung }}$ variabel fasilitas kerja sebesar 4.236. Karena nilai $t_{\text {hitung }}>t_{\text {tabel }}(4.236>1.988)$ dan nilai signifikasi $0.000<0.05$, sehingga $\mathrm{H}_{0}$ ditolak dan $\mathrm{H}_{1}$ diterima. Artinya hipotesis yang diajukan dalam penelitian ini diterima yaitu variabel fasilitas kerja secara partial berpengaruh positif dan signifikan terhadap kinerja pegawai di Kantor Pelayanan Pajak Pratama Medan Petisah. Hasil penelitian ini menjelaskan bahwa semakin baik fasilitas kerja maka semakin tinggi kinerja pegawai di Kantor Pelayanan Pajak Pratama Medan Petisah.

\subsubsection{Pengaruh Motivasi, Kemampuan Kerja dan Fasilitas Kerja Terhadap Kinerja Pegawai di Kantor Pelayanan Pajak Pratama Medan Petisah.}

Untuk mengetahui pengaruh motivasi, kemampuan kerja dan fasilitas kerja terhadap kinerja pegawai di Kantor Pelayanan Pajak Pratama Medan Petisah digunakan uji-F, dengan ketentuan sebagai berkut : 
1) Jika nilai $F_{\text {hitung }}>F_{\text {tabel }}$ dan nilai probabilitas (p) $<$ tingkat signifikansi $5 \%(\alpha=0,05)$ maka hipotesis penelitian $\left(\mathrm{H}_{1}\right)$ diterima dan $\mathrm{H}_{0}$ ditolak, berarti ada pengaruh signifikan antara motivasi, kemampuan kerja dan fasilitas kerja terhadap kinerja.

2) Jika nilai $F_{\text {hitung }}<F_{\text {tabel }}$ dan nilai probabilitas (p) > tingkat signifikansi 5\% $(\alpha=0,05)$ maka hipotesis penelitian $\left(\mathrm{H}_{1}\right)$ ditolak dan
$\mathrm{H}_{0}$ diterima, berarti tidak ada pengaruh signifikan antara motivasi, kemampuan kerja dan fasilitas kerja terhadap kinerja.

Penelitian ini menggunakan taraf signifikansi $(\alpha \quad 0,05)$ dan Derajat Kebebasan (DK) dengan ketentuan numerator : jumlah variabel -1 atau $4-1=3$, dan jumlah sampel dikurang 4 atau $88-4=84$. Dengan ketentuan tersebut, diperoleh nilai $\mathrm{F}_{\text {tabel }}$ sebesar 2.48 .

Tabel 14

Anova ${ }^{\mathrm{b}}$

\begin{tabular}{|l|l|c|r|r|r|c|}
\hline Model & & $\begin{array}{c}\text { Sum of } \\
\text { Squares }\end{array}$ & \multicolumn{1}{c|}{ df } & $\begin{array}{c}\text { Mean } \\
\text { Square }\end{array}$ & F & Sig. \\
\hline \multirow{3}{*}{1} & Regression & 612.460 & 3 & 204.153 & 71.159 & $.000^{\mathrm{a}}$ \\
\cline { 2 - 7 } & Residual & 240.995 & 84 & 2.869 & & \\
\cline { 2 - 7 } & Total & 853.455 & 87 & & & \\
\hline
\end{tabular}

a Predictors: (Constant), Motivasi, Kemampuan, Fasilitas

Dependent Variable : Kinerja

Berdasarkan Tabel 5.23, out put SPSS "Anova" diatas diketahui nilai $\mathrm{F}_{\text {hitung }}>\mathrm{F}_{\text {tabel }}(71.159>$ 2.48) dan nilai signifikasi $0.000<0.05$, sehingga $\mathrm{H}_{0}$ ditolak dan $\mathrm{H}_{1}$ diterima. Artinya variabel motivasi, kemampuan kerja dan fasilitas kerja secara simultan atau bersamasama berpengaruh positif dan signifikan terhadap kinerja pegawai di Kantor Pelayanan Pajak Pratama Medan Petisah.

\subsection{Uji Determinan $\left(\mathbf{R}^{2}\right)$}

Uji determinan adalah untuk melihat seberapa besar pengaruh variabel motivasi, kemampuan kerja dan fasilitas kerja terhadap kinerja pegawai di Kantor Pelayanan Pajak Pratama Medan Petisah secara simultan, maka dapat dilihat dari hasil perhitungan dalam model summary, khususnya angka $\mathrm{R}_{\text {Square }}$ dibawah ini :

Tabel 15

Model summary ${ }^{\mathrm{b}}$

\begin{tabular}{|l|l|r|r|r|}
\hline Model & R & R Square & $\begin{array}{c}\text { Adjusted R } \\
\text { Square }\end{array}$ & Std. Error of the Estimate \\
\hline 1 & $.847^{\mathrm{a}}$ & .718 & .708 & 1.69381 \\
\hline
\end{tabular}

a Predictors: (Constant), Motivasi, Kemampuan, Fasilitas

Dependent Variable: Kinerja

Berdasarkan Tabel 5.24, out put SPSS "Model summary" diatas, diperoleh nilai $\mathrm{R}_{\text {Square }}\left(\mathrm{r}^{2}\right)$ adalah 0.718. Nilai tersebut mempunyai maksud bahwa pengaruh variabel motivasi, kemampuan kerja dan fasilitas kerja terhadap kinerja pegawai di Kantor Pelayanan Pajak Pratama Medan Petisah sebesar 71.80\%, sedangkan sisanya sebesar $28.20 \%$ (100\% $71.80 \%$ ) dipengaruhi oleh faktor-faktor lain yang tidak diteliti. Dengan kata lain variabilitas kinerja pegawai di Kantor Pelayanan Pajak Pratama Medan Petisah dapat diterangkan oleh variabel motivasi, kemampuan kerja dan fasilitas kerja sebesar $71.80 \%$, sedangkan sisanya sebesar $28.20 \%$ disebabkan oleh variabel-variabel lain yang tidak diteliti.

\section{Kesimpulan}

Berdasarkan analisis dan evaluasi data yang telah dijabarkan pada bab sebelumnya baik secara kualitatif maupun kuantitatif, maka dapat disusun kesimpulan dalam penelitian ini yaitu :

1. Variabel motivasi berpengaruh positif dan signifikan terhadap kinerja pegawai Kantor Pelayanan Pajak Pratama Medan Petisah. Hal ini berarti semakin baik motivasi maka semakin tinggi kinerja pegawai.

2. Variabel kemampuan kerja berpengaruh positif dan signifikan terhadap kinerja pegawai Kantor Pelayanan Pajak Pratama Medan Petisah. Hal ini berarti semakin baik kemampuan kerja maka semakin tinggi kinerja pegawai.

3. Variabel fasilitas kerja berpengaruh positif dan signifikan terhadap kinerja pegawai 
Kantor Pelayanan Pajak Pratama Medan Petisah. Hal ini berarti semakin baik fasilitas kerja maka semakin tinggi kinerja pegawai.

4. Variabel motivasi, kemampuan kerja, fasilitas kerja berpengaruh positif dan signifikan terhadap kinerja pegawai Kantor Pelayanan Pajak Pratama Medan Petisah. Hal ini berarti semakin baik motivasi, kemampuan kerja, fasilitas kerja maka semakin tinggi kinerja pegawai.

\section{DAFTAR PUSTAKA}

Ageng Prawatya (2015), Pengaruh motivasi, kemampuan dan disiplin kerja terhadap kinerja Karyawan pada PT. PLN Cabang Weleri

Barker, Alan (2002), Mengelola Sumber Daya Manusia, PT. Gramedia, Jakarta.

Cascio, Wayne F.,( (2006) Managing Human Resources: Productivity, Quality of Work Life, Profits, edition, New York, McGraw Hill

Colquitt, J. A., LePine, J. A., and Wesson., (2009) Organizational Behavior: Improving Performance and Commitment in the Workplace, New York, McGraw Hill, pp. 37

Cross, T.M dan Lynch. R.R. (2006). Peniliaian dan Evaluasi Kinerja: Konsep dan Praktik. Jakarta. Penerbit Ghalia Indonesia

Dessler, Garry (2007), Manajemen Sumber Daya Manusia, PT. Preshelindo, Jakarta.

Gardener, Howard. (2004), Teori Inteligensi Ganda dan Aplikasinya Di Instansi. Yogyakarta : Kanisius

Gibson, James L., Ivancevich, John M., Donnely, James H., and Konopaske (2009) Organizations: Behavior, Structure, Processes,New York, McGraw Hill.

Handoko T, Hani (2008), Manajemen Personalia dan Sumber Daya Manusia, Edisi Kedua, BPFE Yogyakarta.

Hasibuan, Malayu, SP (2008), Manajemen Sumber Daya Manusia, PT. Bumi Akasara Jakarta.

Ishak Arep, dan Hendri Tanjung. 2004. Manajemen Motivasi. Grasindo, Jakarta.

Mangkunegara, Anwar, Prabu. (2009). Evaluasi Kinerja SDM, Cetakan 4, Bandung : Refika Aditama

Murphy, S. E., and Pirozzolo, F. J., (2002) Multi Journal ple Intelligences and Leadership, New Jersey, Lawrence Erlbaum
Nitisemito S Alex (2009), Manajemen Personalia, Cetakan Keempat, Ghalia, Jakarta.

Purwanto, Ngalim (2003), Psikologi Instansi. Bandung : PT. Remaja Rosdakarya

Regina Aditya Reza (2010), Pengaruh gaya kepemimpinan, motivasi dan disiplin terhadap kinerja karyawan PT. Sinar Santosa Perkasa Banjarnegara.

Ridwan. (2007). Skala Pengukuran VariabelVariabel Bandung: Alfabeta

Rivai, Veithzal dan Sagala, Ella Jauvani. (2009). Manajemen Sumber Daya Manusia Untuk Perusahaan : Dari Teori ke Praktek. Jakarta : PT. Rajagrafindo Persada

Robbins P. Stephen, Coulter Mary alih bahasa oleh Benyamin, (2009), Manajemen, Edisi keenam, Jilid 2, PT. Indeks Jakarta

Santoso, Singgih (2004), SPSS Statistik Parametrik, PT. Alex Media Komputindo, Kelompok Gramedia Jakarta.

Sedarmayanti. (2009), Good Governance (Kepemerintahan Yang Baik), Bandung : Mandar Maju

Siagian P. Sondang (2008), Organisasi Kepemimpinan dan Prilaku Organisasi, Gunung Agung Jakarta

Simamora, H. (2004), Manajemen Sumber Daya Manusia. Edisi Ketiga. Yogyakarta: Sekolah Tinggi Ilmu Ekonomi YKPN

Sink, R dan Tuttle, J.K. (2008). Evaluasi Kinerja. Jakarta: Indeks Kelompok Gramedia

Soeparwoto,

(2005),

Psikologi

Perkembangan. Semarang. UPT MKK UNNES

Sugiyono (2004), Metode Penelitian, Erlangga Surabaya

Tilaar, H A R. (2002), Instansi Untuk Masyarakat Indonesia Baru. Jakarta : Grasindo

Triton PB (2005), Paradigma Baru Manajemen Sumber Daya Manusia, Tugu Yogyakarta (2006), SPSS 13,00 Terapan, Riset Statistik Parametrik, Andi, Yogyakarta

Wahjosumidjo (2005), Kepemimpinan dan Motivasi, Liberty Yogyakarta

Wibowo, (2007), Manajemen Kinerja. Cetakan Pertama. Jakarta: Raja Grafindo Persada.

Yeltsin Aprrioke Thomas (2010), Pengaruh fasilitas kerja terhadap kinerja PNS di Kantor Dinas Pendidikan Minahasa Tenggara. 